\title{
Reputation Protection on Online Rating Sites
}

\author{
Anne SY Cheung \\ Wolfgang Schulz
}

\author{
Introduction
}

One of the most significant changes effected by the Internet is the making of

information and comments on individuals readily available for viewing by any and all.

This enhanced transparency has created a new business model, and led to the

flourishing of rating, evaluation and even blacklisting sites. ${ }^{1}$ For example, teachers,

lawyers and doctors are now openly rated by their students, ${ }^{2}$ clients $^{3}$ and patients. ${ }^{4}$

Yet, such evaluations are not confined to the job performance arena. For instance,

Open Table is a site that allows customers and restaurant owners alike to identify

customers who are likely to turn up late for their bookings; ${ }^{5}$ Rottenneighbors.com

allows residents to locate unfriendly neighbors; and DontDateHimGirls.com affords

\footnotetext{
${ }^{1}$ In this article, rating sites refer to online platforms that score and rank individuals or businesses. Evaluation sites provide an opportunity for users to post comments on individuals and businesses, in addition to ranking and scoring them. Sacha Pfeiffer, Ratings Sites Flourish behind a Veil of Anonymity, THE Boston GLOBE (2006), available at http://www.boston.com/business/technology/articles/2006/09/20/ratings_sites_flourish_behind_a_veil of_anonymity/ (last visited Jun. 8, 2017).

2 RATE MY PROFESSORS - REVIEW TEACHERS AND PROFESSORS, SCHOOL REVIEWS, COLLEGE CAMPUS RATINGS, http://www.ratemyprofessors.com/. French case of NotetoBe, Cour d'appel de Paris 14ème chambre, section A Arrêt du 25 juin 2008, Note2be.com(2008), available at http://www.legalis.net/spip.php?page=jurisprudence-decision\&id_article=2349. German case of Spickmich, Spickmich.de, BGH 23.06.2009, VI ZR 196/08, (German Federal Supreme Court).

3 The Law Society \& Ors v. Kordowski, [2011] EWHC 3185 (Q.B.). Davis v. Avvo, NO. C11-1571RSM, 2012 WL 1067640 (W.D. Wash. Mar. 28, 2012).

4 Braverman v. Yelp, Inc., 115629/12 (Jun. 28, 2013)

${ }^{5}$ Katie Hafner, Restaurant Reservations Go Online, THE NEW YoRK TIMES, Jun. 182007.
} 
women a platform on which to out terrible boyfriends. ${ }^{6}$ In the words of Lori

Strahlevitz, we are now living in a "reputation nation,"7 wherein various aspects of our conduct are evaluated by often anonymous individuals, ushering in the danger of shame sanctions. Unfair evaluations or personal information taken out of context can lead to misjudgments and misunderstandings, causing potentially serious harm. ${ }^{8}$ Moreover, they can also exert a negative impact on communities as a whole when they rely on models of biased, unfair and incorrect information for judging others.

Although reputation rating sites are far from being a system of formal adjudication, their power can hardly be ignored, especially when evaluations are related to work performance. These sites often post false or incorrect information, and many do not allow individuals to correct such information. Victims in common law jurisdictions may rely on defamation law, but will find themselves helpless against anonymous individuals expressing their opinions online. ${ }^{9}$ Equally, victims in continental law jurisdictions will not necessarily fare any better under privacy law if the information is considered of legitimate public interest and is already in the public

\footnotetext{
6 Todd Hollis v. Cunningham, 1:2007CV23112 (S.D. Fla. filed Nov. 29, 2007).

${ }^{7}$ Lori J. Strahilevitz, Reputation Nation: Law in an Era of Ubiquitous Personal Information, 102 NORTHWESTERN UNIVERSITY LAW REVIEW. 1667 (2008).

8 DANIEL J. SOlOve, Speech, Privacy and Reputation on the Internet, in THE OFFENSIVE INTERNET: SPEECH, PRIVACY, AND REPUTATION 15 (Saul Levmore \& Martha C. Nussbaum eds., 2010).

9 Sophie Kay, Combatting AnOnYMous Online Defamation Conflicts (2016), https://inforrm.wordpress.com/2016/11/05/combatting-anonymous-online-defamation-conflicts-sophiekay/. RonNell Andersen Jones \& Lyrissa Barnett Lidsky, Of Reasonable Readers and Unreasonable Speakers: Libel Law in a Networked World, VA. J. SoC. POLICY LAW 155 (2016).
} 
domain. ${ }^{10}$ Furthermore, litigation is lengthy, costly and plagued with uncertainty. In the absence of satisfactory legal solutions and remedies, some have resorted to alternative methods of "reputation management."11 For example, doctors have been reported to ask patients to sign waiver forms declining to participate in online rating forums before providing consultations, ${ }^{12}$ and a number of companies have been established to help those who have been rated unfavorably to rebuild and "amplify their reputation." 13

Formal and informal norms are gradually emerging to moderate the battle between evaluation and reputation protection, but they remain in a fledgling state and are not without problems. As explained later in the article, reputation is an inherently social and relational concept that "serves an important signaling function" about an individual's place within society. ${ }^{14}$ At the same time, it also reflects the rules of civility within the community: how we manage reputation information to make it reliable and how we draw boundaries between the private and the public. We

\footnotetext{
10 See judgments before the European Court of Human Rights. Von Hannover v. Germany (no. 2) 40660/08 [2012] ECHR 228. Von Hannover v. Germany (no.3) 87712/10 [2013] ECHR 264. The judgment is in French, and the official press release in English. European Court of Human Rights Press Release. "German Courts' Decisions Respected Private and Family Life of Princess Caroline von Hannover.” 19 September 2013, https://rm.coe.int/168067d217 .

${ }^{11}$ Eric Goldman, The Regulation of Reputational Information, THE NEXT DIGITAL DECADE: ESSAYS ON THE FUTURE OF THE INTERNET 293 (2010).

12 Medical Justice, Avoid Being Defamed on the Web: Have you GoOgled Your Name LATELY? available at: https://medicaljustice.com/wp-content/uploads/2012/10/ANTI_DEF_-_MJ_Report.pdf

${ }_{13}$ Examples of companies that offer services claiming to rescue individuals' online reputations include Reputation Defenders, https://www.reputationdefender.com/reputation (Last visited Aug. 1, 2017), and EMERIT - ONLINE REPUTATION MANAGEMENT FOR DOCTORS, https://emerit.biz/ (last visited Aug. 1, 2017).

14 David S. Ardia, Reputation in a Networked World: Revisiting the Social Foundations of Defamation Law, 45 HARV. CR.-CL. REV. 261, 262 (2010).
} 
therefore argue herein that what is preferable for protecting online platform reputation is a legal framework that is responsive to the changing set of practices ushered in by the Internet and can resolve conflicts in a fair and satisfactory way. Drawing on U.S. and German jurisprudence on online evaluation platforms, the article advocates for a new regime requiring such platforms to formulate an appropriate information policy providing transparency rules, including the outlining of how aggregate evaluations are made and catering for the right to respond, among other requirements, to achieve a new body of communication "netiquette" for social evaluation in the online era. These two jurisdictions were chosen because of the popularity of online rating sites in both, as well as the existence of a number of relevant judicial decisions on the subject matter of interest. The concern in this article is the protection of individual reputation rather than those of a business or company. The terms "evaluation sites" and "rating sites," and "online sites" and "online platforms" are used interchangeably throughout the article. ${ }^{15}$

Part I of the article looks at the concept of reputation as interpreted in U.S. common law jurisprudence and the German continental law tradition. Under common

\footnotetext{
15 The distinction between evaluation and rating sites is explained in supra note 1. A website is generally understood to be a web page hosted on a Web server by the site's owner, a hosting provider or an Internet service provider. PC Magazine Encyclopedia at https://www.pcmag.com/encyclopedia/term/54397/website (last visited Aug. 21, 2017). An online marketplace refers to a virtual space in which one party can get in touch with another, such as buyers and sellers. PC Magazine Encyclopedia at https://www.pcmag.com/encyclopedia/term/68953/online-platform (last visited Aug. 21, 2017). As we will see from the discussion in Part II, the U.S. courts use "online sites" to refer to evaluation sites, whereas the German courts generally prefer "platforms."
} 
law, reputation is largely protected through defamation law, the fundamental concern of which is to protect an individual's representation to the world and the world's social construction of his or her identity. German law, in contrast, recognizes the protection of a person's reputation through personality and dignity rights. ${ }^{16}$ In addition to protecting against unwarranted reputational harm and unjustified social condemnation, German law also protects individuals' private sphere. ${ }^{17}$ An overview of the two legal systems affords a better understand of how reputation is protected within embedded systems of social and legal norms. Part II then examines the uphill legal battle that plaintiffs in the U.S. and Germany must wage in the courts against allegedly untrue or misleading comments on online rating platforms. Drawing on the lessons learnt from the two jurisdictions, Part III then argues that we need a new governance regime that allows for the fair play of reputation protection and freedom of expression, taking into account the right to respond and the filtering of incorrect information. Only in this way can we better coordinate legal and social norms, and ultimately decide what kind of online evaluation platforms are reliable and thus deserving of social recognition and legal protection.

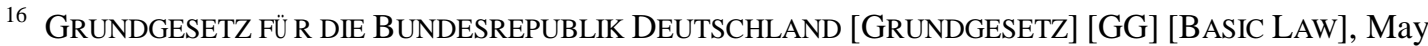
23, 1949 BGBl. I, art. 1(1) \& art. 2(1). For an English translation, see BASIC LAW FOR THE FEDERAL REPUBLIC OF GERMANY, http://www.gesetze-im-internet.de/englisch_gg/englisch_gg.html\#p0019.

17 Edward J. Eberle, Human Dignity, Privacy, and Personality in German and American Constitutional Law, UTAH LAW REV. 963 (1997).
} 


\section{The Concept of Reputation : What's in a Name?}

A well-known verse in the Bible avers that "a good name is more desirable than great riches; to be esteemed is better than silver or gold." ${ }^{18}$ Indeed, there is much truth in the saying that "good reputation [is] painstakingly earned, easily lost and not readily rebuilt." ${ }^{, 19}$ The protection of reputation from unjustified attack has thus long been a common concern of both the common law and continental law traditions. In this part of the article, we discuss the fundamental rationale for the protection of reputation, be it under defamation law or with reference to personality rights, and redraw its socio-legal boundary with freedom of expression in the arena of online rating platforms. In the process, we demonstrate the interconnection of social norms and legal rules and the need for a coherent response.

\section{A. U.S. Common Law Tradition}

Common law has a long tradition of protecting reputation through defamation law. ${ }^{20}$ English and U.S. defamation law had much in common until 1964, when the U.S. Supreme Court handed down its judgment in US Times v. Sullivan, ${ }^{21}$ which set a different legal standard for public —as opposed to private-figures bringing

\footnotetext{
18 The Bible, Proverbs 22:1.

19 David A. Anderson, Reputation, Compensation and Proof, 25 WILLIAM \& MARY LR. 747, 777 (1984).

${ }^{20}$ DANiEl J. Solove, The Future OF RePUTATION 118 (2007)

21 New York Times Co. v. Sullivan, 376 U.S. 254 (1964).
} 
defamation actions. ${ }^{22}$ Although U.S. defamation law varies from state to state, the core elements of liability for defamation are (1) a false and defamatory statement concerning another; (2) an unprivileged publication to a third party; (3) fault amounting at least to negligence on the part of the publisher; and (4) either actionability of the statement irrespective of special harm or the existence of special harm caused by the publication. ${ }^{23}$ Consistent with the English common law tradition, U.S. defamation law protects against the publication of false rumors about a person that "exposes [the] person to hatred, ridicule, contempt or obloquy, or cause[s] him to be shunned and avoided." 24 A defamatory statement is one that would generally tend to lower the plaintiff in the estimation of right-thinking members of society. ${ }^{25}$ In this understanding, a person's reputation is largely dependent on his or her estimation in the minds of third parties. However, the exact definition of reputation remains obscure despite a long line of defamation cases. ${ }^{26}$

Thus, it is necessary for us to go back in time to examine the goals of reputation protection. In his seminal piece on the socio-historical and legal study of defamation

\footnotetext{
22 "Under the Sullivan test, plaintiffs who are public officials or public figure has to prove the defendant has published the defamatory statement with actual malice, i.e. the defendant published the statement knowing it to be false, or with reckless disregard as to its falsity." (quoting New York Times Co. v. Sullivan, 376 U.S. 254, 279-80 (1964).) Under English defamation law, no such distinction is made. See discussion in ANDrew T. KenYon, DeFamation: Comparative LaW AND PRACTice 240 241 (2006).

${ }^{23}$ Restatement (Second) of Torts $§ 558$ (Am. Law Inst. 1977).

${ }^{24}$ Youssoupoff v. MGM Pictures Ltd., 50 TLR 581 at 587 (C.A.). Id., § 559.

${ }^{25}$ Sim v. Stretch, [1936] 2 All ER 1237 at 1240 (H.L.). Restatement (Second) of Torts, supra note 23, $\S 559$.

${ }^{26}$ Eric Barendt, What is the Point of Libel Law?, 52 CURR. LEG. ProBL. 110-125 (1999).
} 
law, Robert Post identifies reputation as property, honor and dignity. ${ }^{27}$ According to Post, reputation as property refers to "reputation in the marketplace."28 An individual can earn recognition and build up his or her reputation by "the exertion of talent" or "mechanical skill and ingenuity," $" 29$ namely, through skill, labor and effort. An apt illustration is professional reputation. ${ }^{30}$ The law of defamation is designed to ensure that a person's reputation is "not wrongfully deprived of its proper market value.",31

At the same time, Post also considers reputation to be a form of honor owing to the venerable tradition of social rank or position conferred upon individuals since the times of feudalism and the aristocracy. ${ }^{32}$ Different from reputation as property, reputation as honor cannot be earned through effort or labor. It is a reflection of the status that society ascribes to one's social position or specifically defined social role. A loss of honor is thus a loss of status and personal identity, ${ }^{33}$ the restoration of which can only be "vindicated." 34 For Post, this fact explains the underlying rationale for criminal libel and seditious libel in English law. ${ }^{35}$

\footnotetext{
27 Robert C. Post, The Social Foundations of Defamation Law: Reputation and the Constitution, 74 CALIF. LAW REV. 691, 692 (1986). For analysis of his piece, see Barendt, supra note 26. DAVID ROLPH, REPUTATION, CELEBRITY AND DEFAMATION LAW 87-168 (2008).

${ }^{28}$ Post, id. at 693.

${ }^{29}$ Id. at 694.

30 Post also cites the example of building up a reputation through "a course of virtuous and honorable action[s]." Id. at 694-695.

${ }^{31} I d$. at 695.

${ }^{32}$ Id. at $701-702$.

${ }^{33} I d$. at 691, 703.

34 Robert C. Post, The Social Foundations of Defamation Law: Reputation and the Constitution, 74 CALIF. LAW REV. 691, 703 (1986).

${ }^{35}$ Id. at $702-703$.
} 
Lastly, Post points out that reputation is also linked to the concept of dignity, by which he is referring to the "essential dignity and worth of every human being - a concept at the root of any decent system of ordered liberty." ${ }^{\text {,6 }}$ We earlier noted Post's emphasis on the social and public nature of reputation, being bestowed by others and concerning the esteem in which one is held by the community. Here, however, Post highlights the "person's private personality" as his (or her) "essential dignity.",37 Aware of the apparent paradox, Post reconciles it by drawing on the work of Ervin Goffman, specifically the famous sociologist's work on the symbolic interaction tradition. ${ }^{38}$ Our identity and sense of who we are, in Goffman's view, are constantly being molded through social interactions with others. ${ }^{39}$ Each of us is both a subject and object at the same time. ${ }^{40}$ Applying this conceptualization, Post suggests that our own sense of intrinsic worth is "perpetually dependent upon the ceremonial observation by those around us." 41 The law of defamation functions as norms of "deference and demeanor," 42 as well as "rules of civility" that members of society owe to one another to protect the internal aspect of individual personality and

\footnotetext{
${ }^{36} I d$. at 707. Post is quoting Justice Stewart's dictum in Rosenblatt v Baer, 383 U.S. 75, 92 (1966).

${ }^{37} I d$. at 708.

${ }^{38} I d$. at 709-712. ERVING GOFFMAN, INTERACTION RITUAL 84-85 (1967).

${ }^{39} I d$. at 709.

40 Thomas Gibbons, Personality Rights: The Limits of Personal Accountability, 3 YEARB. OF MEDIA AND ENTERTAIN. LAW 53, 58 (1998). Gibbons discusses Post's article and its relation with Goffman's work.

41 Post, supra note 27 at 711.

42 Post, supra note 34 at 709.
} 
individuals' intrinsic self-worth. ${ }^{43}$ From this perspective, reputation has both a private and public dimension. It protects the private sphere, the internal aspect of an individual's interest in his or her own dignity as a person, while at the same time being concerned with the public sphere, particularly society's interest in maintaining its own rules of decency and governing how members conduct themselves in the exercise of speech.

The three foregoing characteristics of reputation are not mutually exclusive, and none is entirely satisfying on its own, and yet they throw light on different aspects of defamation law. The unifying feature among them is the "dependence of an individual's reputation on the recognition of others." 44 Reputation is thus indisputably an inherently relational, ${ }^{45}$ and a distinctly social concept.

\section{B. German Law}

The link between an individual and the community is prominent in German law, under which there are different ways of protecting a person's reputation. Defamation in itself is primarily a misdemeanor governed under sections 186-189

\footnotetext{
${ }^{43} I d$. at 710.

44 David Rolph, Reputation, Celebrity and Defamation LaW 3 (2008). Rolph discusses Post's work.

${ }^{45}$ Id. at 37 .
} 
of the Criminal Code (Strafgesetzbuch, StGB). ${ }^{46}$ In private conflicts, what in fact corresponds to the tort of defamation under English or U.S. common law would be recognized as the right of personality (allgemeines Persoenlichkeitsrecht), which is protected under section 823(1) of the Civil Code (Buergeliches Gesetzbuch, BGB), ${ }^{47}$ and article 2(1) of the German Constitution or Basic Law (Grundgesetz). The latter guarantees the right to free development of one's personality. However, the interpretation of personality rights protected under article 2(1) of that section must be read in conjunction with article 1(1) of the Basic Law which protects the right to human dignity. ${ }^{48}$

Interestingly, the Civil Code contains no reference to the term "personality." Section 823(1) protects specific interests against intentional and negligent invasion, stating:

A person who, intentionally or negligently, unlawfully injures the life, body,

health, freedom, property or another right of another person is liable to make

\footnotetext{
46 BASIL S. MARKESINIS \& HANNES UnBERATH, THE GERMAN LAW OF TORTS: A COMPARATIVE TREATISE 27 (2002). Strafgesetzbuch (StGB) (German Criminal Code). For an English translation, see GERMAN CRIMINAL CODE, https://www.gesetze-im-internet.de/englisch_stgb/.

47 RAYMOND Youngs, ENGLISH FRENCH \& GERMAN COMPARATIVE LAW 436 (3d ed. 2014). BGHZ 39, 124 (127). BVERFGE 97, 391 (403). BGHZ 198, 346 ff. Murswiek, in: Michael Sachs (Ed), Grundgesetz-Kommentar, Munich 2016, Art. 2, marginal no. 67 et seq.

48 BVerfGE 34, 238 ff; 35, 202 ff. Rudolf Streinz, The Role of the German Federal Constitutional Court Law and Politics, 31 RITSUMEIKAN LR. 95 (2014), (104). THOMAS HOEREN \& ANSELM RoDEnHAUSEn, Constitutional Rights and New Technologies in Germany, in CONSTITUTIONAL RIGHTS AND New TEChNOlogIES: A Comparative Study 137 (138 et seq) (Ronald Leenes, Bert-Jaan Koops \& Paul D. Hert et al. eds., 2008). Article 1 of the German Constitution stipulates that "(1) Human dignity shall be inviolable. To respect and protect it shall be the duty of all state authority." Article 2 stipulates that (1) Every person shall have the right to free development of his personality insofar as he does not violate the rights of others or offend against the constitutional order or the moral law. BASIC LAW FOR THE FEDERAL REPUBLIC OF GERMANY, https://www.gesetze-im-internet.de/englisch_gg/ (last visited Jun. 8, 2017).
} 
compensation to the other party for the damage arising from this [emphasis added . $^{49}$

The absence of the term "personality right" is largely due to historical developments. Different from most other continental law jurisdictions, Germany never adopted the term "personality," which is rooted in the Roman legal concept of delict injuria. ${ }^{50}$ Although well-recognized in Roman law to protect a person's dignity from injuries to reputation and feelings, ${ }^{51}$ personality rights were deliberately left out when the Civil Code was drafted in 1900. General opinion at the time held that it was repugnant to compensate such an important intangible interest in financial terms. ${ }^{52}$ However, sentiments changed dramatically after the Second World War, in light of the defeated Nazi regime's ruthless trampling of any respect for human life, liberty or dignity. ${ }^{53}$ Not only does the German Constitution of 1949 expressly protect the dignity of man as inviolable under article 1(1), but it also stipulates under article 2 that "everyone shall have the right to the free development of his personality insofar as he does not violate the rights of others or

\footnotetext{
49 GERMAN CIVIL CODE, https://www.gesetze-im-internet.de/englisch bgb/(last visited Aug. 3, 2017)

50 P. R. Handford, Moral Damage in Germany, 4 INT. CoMP. LAW Q. 849, 851 (1978).

${ }^{51} I d$. at 851.

${ }^{52} I d$. at 855. BASIL S MARKESINIS \& HANNES UnBERATH, THE GERMAN LAW OF TORTS: A COMPARATIVE TREATISE 74 (2002).

53 Thomas Gibbons, Personality Rights: The Limits of Personal Accountability, YEARB. MEDIA ENTERTAIN. LAW 53, 56 (1997).
} 
offend against the constitutional order or the moral law,"54 and the German courts have since adopted an expansive approach to the interpretation of BG section 823 .

In 1954, for example, the German Federal Supreme Court (Bundesgerichtshof BGH) declared in Schacht that the defendant, a newspaper, had violated "a general right of personality" under articles 1(1) and 2(1) of the Basic Law. ${ }^{55}$ The case concerned a letter written to the newspaper by Schacht's lawyer, the plaintiff, demanding that certain statements about Schacht be corrected. ${ }^{56}$ The interesting background to the case is that Schacht had served as Germany's Economics Minister under Hitler. ${ }^{57}$ Instead of issuing the correction requested, the newspaper published the letter with other materials giving the misleading impression that Schacht's lawyer had taken a personal stance in the matter. ${ }^{58}$ The German Federal Supreme Court ruled in favor of the plaintiff, denouncing the defendant for infringing the plaintiff's right of personality, as protected under the Basic Law, by publishing the materials in such a misleading manner, ${ }^{59}$ and ordered a correction. ${ }^{60}$ The significance of Schacht is that from that point onwards, the right of personality

\footnotetext{
${ }^{54}$ Basic Law For The Federal Republic of Germany, supra note 48.

55 BGHZ 13, 334. For discussion of the case, see Handford, supra note 50 at 859 . For a case summary and English translation of the case, see MARKESINIS \& UNBERATH, supra note 52 at 412-415.

56 MARKESINIS AND UNBERATH, supra note 52 at 413.

${ }^{57}$ Handford, supra note 50 at 858.

${ }^{58}$ MARKESINIS AND UNBERATH, supra note 52 at 412-413.

59 Id. at 415.

${ }^{60}$ Id. at 415.
} 
has been firmly recognized in Germany as an enforceable right rather than as an abstract ideal in the Constitution.

Another significant case was the 1958 decision in which the Federal Supreme Court held that the general right of personality should be recognized as one of the "other rights" under section 823(1) of the Civil Code, thereby confirming the direct connection between the Civil Code and the Basic Law in the right's protection. ${ }^{61}$ Soon after, the Federal Supreme Court awarded compensation for violation of the right of personality based on the Civil Code and the Basic Law in Herrenreiter. ${ }^{62}$ The plaintiff in that case was a successful amateur show-jumper, and the defendant was a pharmaceutical company specializing in the manufacture of a sexual potency enhancement drug. ${ }^{63}$ In one of its promotional posters, the defendant had featured a picture of a show-jumper based on the plaintiff's photograph. ${ }^{64}$ The plaintiff was understandably offended, as permission had never been sought, and sued for damages. ${ }^{65}$ The Federal Supreme Court ruled that his right of personality had been infringed under section 823(1) of the Civil Code and articles 1 and 2 of the Basic Law. $^{66}$

\footnotetext{
${ }^{61}$ BGHZ 24, 72. The case concerns the unlawful release of an insured person's medical records. Handford, supra note 50 at 859. see MARKESINIS \& UNBERATH, supra note 52 at 473.

62 BGHZ 26, 349. For a case summary and English translation of the case, see MARKESINIS \& UNBERATH, supra note 52 at 415-420.

63 MARKESINIS AND UNBERATH, supra note 52 at 415.

64 Id.

${ }^{6} \mathrm{Id}$.

${ }^{66} I d$. at 416.
} 
It is the Court's analysis of the meaning of "personality right" that provides insight for our discussion. Most importantly, the Court affirmed that the combined effect of the dignity and personality rights enshrined in the Basic Law recognizes human personalities as "supra-legal basic values" of the law. ${ }^{67}$ The two rights protect the "inner realm of the personality," which provides the basis for the free and responsible self-determination of an individual. ${ }^{68}$ Any invasion of that realm must be compensated. A right of personality is characterized as the "inner freedom" $" 69$ to have interests and make one's own decisions in the individual sphere.

The emphasis on protection of the personal sphere and analysis on its meaning were further elaborated in later cases. ${ }^{70}$ In essence, the personal sphere embraces (1) the individual sphere preserving personal individuality in one's relationship with the wider world, particularly in one's public sphere of influence; (2) the private sphere, which includes an individual's family and private life; and (3) the intimate or secret sphere, which refers to an individual's inner thoughts and feelings

\footnotetext{
${ }^{67}$ MARKESINIS AND UNBERATH, supra note 50 at 418.

68 MARKESINIS AND UNBERATH, supra note 52.

${ }^{69}$ MARKESINIS AND UNBERATH, supra note 50.

${ }^{70}$ Handford, supra note 50 at 860. Edward J. Eberle, Human Dignity, Privacy, and Personality in German and American Constitutional Law, UTAH LAW REV. 963, 979 (1997).
} 
and their external forms. ${ }^{71}$ Thus, the personal sphere carves out the necessary space to determine who one is and how one should relate to the world. ${ }^{72}$

Readers may already have noticed the differences between the common law and German legal approaches to the protection of reputation. Common law protects reputation through defamation law, and the aim is to protect a person's name against wrongful or untrue social appraisals by others. The German law on personality rights, in contrast, protects an individual's name to allow him or her to expressively develop his or her whole being within different societal contexts. ${ }^{73}$ The law of personality sets the boundaries of when and within what limits personal life circumstances may be revealed or how a person may be criticized. Although that law bears a close resemblance to the right to be left alone in U.S. privacy law, ${ }^{74}$ and to Post's analysis of reputation as dignity (protecting a person's sense of intrinsic worth and society's rules of civility), ${ }^{75}$ the scope of the multifaceted personality right goes well beyond the common law understanding.

The case law established by the Federal Constitutional Court (Bundesverfassungsgericht, BVerfG) illustrates the additional dimensions of the

\footnotetext{
71 Handford, supra note 50 at 860.

72 Eberle, supra note 17 at 980.

73 Wolfgang Schulz \& Max V. Grafenstein, The Right to be Forgotten in Data Protection Law: A Search for the Concept of Protection, InT. JouRnal OF PUBLIC LAW AND POLICY 5, 249-269 (2015).

${ }^{74}$ Referring to the famous phrase of Warren and Brandeis in advocating for the recognition of a right to privacy in U.S. common law; see Samuel D. Warren \& Louis D. Brandeis, The Right to Privacy, 4 HARV. LAW REV. 193, 195 (1890).

75 Post, supra note 34 at 707-708.
} 
right of personality, referring to the different interests a person can have that are relevant to the protection of his or her reputation. ${ }^{76}$ Because right of personality in Germany is based on the combined jurisprudence of articles 1(1) and 2(1) of the Basic Law (which cover human dignity and the free development of personality, respectively), ${ }^{77}$ it is also important to consider the Federal Constitutional Court's interpretation of human dignity under article 1 of the Basic Law.

Closely related to right of personality and dignity is personal honor. ${ }^{78}$ Different from Post's analysis of honor as an aristocratic notion in English society, honor in German law refers to the respect that each and every person should be accorded based on his or her personhood. Accordingly, honor is related to protection of the individual sphere. ${ }^{79}$ This embedded element in the right of personality means that abusive criticism (Schmähkritik) cannot be tolerated. ${ }^{80}$ However, owing to the protection of free speech under article 5(1) of the Basic Law, only speech that is demeaning without any factual basis is banned. ${ }^{81}$

\footnotetext{
76 Eberle, supra note 17 at 1014.

77 BGHZ 13, 334 (338); 26, 349 (354); BVerfGE 35, 202 (220); 54, 148 (153). Judith Janna Maerten, Personality Rights and Freedom of Expression: A Journey through the Development of German Jurisprudence under the Influence of the European Court of Human Rights, 2 J. MEDIA LAW 333-349 (2012).

${ }^{78}$ Handford, supra note 50 at 860.

${ }^{79}$ BVerfGE 87, 209 (228).

80 AG Dannenberg, 13 December 2005 - 31 C 452/05 (I), published in MMR 2006, 567 et seq.

81 BVERFGE 99, 185 (199 f.). Dieter Grimm, Die Meinungsfreiheit in der Rechtsprechung des Bundesverfassungsgerichts (The Freedom of Speech in Judicature of the German Constitutional Court), N.J.W. 1697-1703 (1995).
} 
The right of personality also protects one's private sphere or privacy. ${ }^{82}$ This includes private and confidential matters including the disclosure of details about a person's sex life or medical condition. ${ }^{83}$ In addition, the protection extends to a spatial area in public where the individual can move and relax, free from continual public observation and scrutiny. ${ }^{84}$

Finally, the fundamental rights dimension of data protection and the right to informational self-determination also play a role in consideration of the right of personality, as personal data, e.g., one's name or address, may serve as indicators of reputation. ${ }^{85}$ The concept of informational self-determination is formulated by the German Constitutional Court in the famous Census Case of $1983 .{ }^{86}$ The Court declared certain provisions of the Census Act which mandated the collection of comprehensive data of citizens to be intrusive and unconstitutional. ${ }^{87}$ The concern was that massive and comprehensive surveys of the population, coupled with computing technology, would facilitate the state to control its citizens. ${ }^{88}$ Informational self-determination is interpreted as "the authority of the individual to

\footnotetext{
${ }^{82}$ MARKESINIS AND UNBERATH, supra note 52 at 450 . Maerten, supra note 77 at 334.

${ }^{83}$ Maerten, supra note 77 at 334.

${ }^{84}$ MARKESINIS AND UNBERATH, supra note 52 at 455.

${ }_{85}^{85}$ BVERFGE $i d$. Fabio, id., marginal no. 173 et seq.

86 BVerfGE 651 (1983). For discussion, see Eberle, supra note 17 at 1000. Antoinette Rouvroy \& Yves Poullet, The Right to Informational Self-Determination and the Value of Self-Development:

Reassessing the Importance of Privacy for Democracy, in REINVENTING DATA PROTECTION? 45-76 (2009).

87 Id.

${ }^{88}$ Eberle, supra note 17 at 1001.
} 
decide himself, on the basis of the idea of self-determination, when and within what limits information about his private life should be communicated to others." 89

Rather than distinct categories, the aforementioned rights to honor, private sphere, data protection and informational self-determination constitute separate aims of protection under the right of personality. German tort law permits claims for all three types of interests (see section 823 Civil Code).$^{90}$ There are also additional safeguards such as right to one's own identity, ${ }^{91}$ special duties for a controller of personal data, ${ }^{92}$ as well as clauses on defamation in criminal law protecting honor. $^{93}$

The focus of the discourse on right of personality and reputation in German law is on the individual and how he or she relates to others in society. The individual is first and foremost a social being. As discussed in the next section, the preservation of the personal and private spheres under the right of personality is facing severe challenges in the Internet era. An individual's personal information can be easily searched and retrieved, and comments about him or her (including criticism and

\footnotetext{
${ }^{89}$ Rouvroy and Poullet, supra note 88 at 45.

90 BGHZ 39, 124 (127). BVERFGE 97, 391 (403). BGHZ 198, 346 ff. Murswiek, supra note 47.

91 This refers to an individual's interest in determining his or her representation in public. BVERFGE 54, 148 (155). Udo Di Fabio, in: Theodor Maunz, Günter Dürig (Eds), Grundgesetz-Kommentar, Munich 2016, Art. 2, marginal no. 166 et seq. This includes one's right not to be mis-represented to the public or placed in a false light. For instance, false citations in political debates attributed to one, and fictitious interviews of famous persons were considered as violations of right of personality. GERT BRÜGGEMEIER, MODERNISING CIVIL LIABILITY LAW IN EUROPE, CHINA, BRAZIL AND RUSSIA: TEXTS AND COMMENTARIES 35 (2011).

92 Edith Palmer, Online Privacy Law: Germany, https://www.loc.gov/law/help/online-privacy-law/germany.php (last visited Jun. 11, 2017).

93 StRafGesetzBuch [StGB] [PENAL CODE], §§ 186-190
} 
insults) can be readily posted for all to see

The way in which reputation is framed is clearly highly dependent on cultural and philosophical contexts and the characteristics of the legal system. Because the protection of reputation is intertwined with the social norms of the community, the challenges for the online community are determining what types of information are appropriate for sharing with the public and how information can be shared in a fair manner. The legal challenge is to find the delicate balance between an individual's reputation on the one hand and others' freedom of expression and the public's right to certain personal information on the other.

\section{Legal Battle over Online Evaluation Sites}

\section{A. U.S. Law}

As noted at the start of this article, society has long attributed reputation to individuals through evaluation, a practice that is being prominently played out on the Internet. Subjects of negative evaluations are understandably offended and frustrated. If they know the identity of the person who has posted a negative review about them on a rating site, they can bring a defamation action against that person, as in McKee $v$. Laurion. $^{94}$ The plaintiff in that case was a physician who unsuccessfully sued a

\footnotetext{
94 McKee v. Laurion, 825 N.W. 2d 725 (2013).
} 
patient's son for posting negative reviews of the plaintiff on various "rate-your-doctor" websites. ${ }^{95}$ However, it is more common for plaintiffs not to know who has posted defamatory content, and their only recourse is thus to sue the website operator. As explained below, this kind of legal battle has proved to be an uphill one in the U.S.

The plaintiff in Reit v. Yelp! $!^{96}$ was a dentist who sued Yelp! for defamation after the company removed all ten positive reviews of the plaintiff's practice following the posting of a single negative comment by an anonymous poster. ${ }^{97}$ Yelp! is an interactive online platform that allows the general public to write, post and view reviews of a variety of businesses and professionals, including restaurants and other service establishments and doctors and dentists. ${ }^{98}$ It also sells and solicits advertisements. ${ }^{99}$ The plaintiff alleged that removing positive reviews and highlighting negative ones was part of Yelp's business model and was designed to coerce businesses and professionals into paying for advertising on Yelp.com. ${ }^{100}$

Yelp! claimed that it was immune to defamation liability under the Federal Communications Decency Act (CDA) ${ }^{101}$ because it was an Internet computer service and not an information content provider. ${ }^{102}$ Section $230(\mathrm{c})$ of the CDA states that

\footnotetext{
95 Id. The court ruled that the statements were pure opinion, which is protected under the First Amendment.

96 Reit v. Yelp! Inc. and John Doe, aka Michael S., 29 Misc. 3d 713 (2010).

97 Id. at 715.

98 Id. and Yelp, About Us at https://www.yelp.com/about (last visited Aug. 31, 2017).

99 Reit v. Yelp! Inc. and John Doe, supra note 96.

${ }^{100}$ Id.

101 Federal Communications Decency Act 47 U.S.C. $§ 230$ (1996).

102 Id.
} 
"[n]o provider or user of an interactive computer service shall be treated as the publisher or speaker of any information provided by another information content provider." In addition, under section 230(e), "[n]o cause of action may be brought and no liability may be imposed under any State or local law that is inconsistent with this section." The same law defines an interactive computer service as "any information service, system or access software provider that provides or enables computer access by multiple users to a computer server, ${ }^{, 103}$ and an information content provider as "any person or entity that is responsible, in whole or in part, for the creation or development of information provided through the Internet or any other information computer service." ${ }^{104}$ Section 230 of the CDA is often seen as a protector of online free speech as it absolves intermediaries of legal liabilities. ${ }^{105}$

Although the plaintiff in Reit argued that the selective removal of all of his positive reviews was more than the exercise of a publisher's traditional editorial function, rendering the company an Internet content provider, ${ }^{106}$ the Court ruled otherwise. In the Court's opinion, as long as the allegedly defamatory content was supplied by a third party, the defendant's use of negative posts or reviews in its

\footnotetext{
103 Id. at $\$ 230(\mathrm{f})(2)$.

104 Id. at $\$ 230(\mathrm{f})(3)$.

105 Paul Ehrlich, Communications Decency Act Section 230, 17 BERKELEY TECHNOL. LAW J. 401 (2002). Daniel Solove, Speech, Privacy and Reputation on the Internet, in THE OFFENSIVE INTERNET: SPEECH, PRIVACY, AND REPUTATION 15, 23 (Saul Levmore \& Martha C Nussbaum eds., 2010). ${ }^{106}$ Reit v. Yelp!, supra note 96 at 716.
} 
marketing strategy did not change the nature of the posted data. ${ }^{107}$ Its selection of posts constituted an action "quintessentially related to a publisher's role" and not that of a content provider. ${ }^{108}$

In the cause of action, the plaintiff further alleged that Yelp! engaged in deceptive acts and practices in violation of the General Business Law. ${ }^{109}$ For that law to offer remedy, however, a plaintiff must prove that the deceptive conduct in question must be misleading to a reasonable consumer, and the injury must be an actual injury. ${ }^{110}$ Because the plaintiff referred to the text of Yelp's Business Owner's Guide as the basis for its allegedly deceptive practices, his action failed because the Court concluded that the Guide addressed business owners rather than consumers. ${ }^{111}$

If removing positive comments does not render Yelp! a content provider, what about the inclusion of a "Best of Yelp!" page? The plaintiff in Braverman v. Yelp! !12 found himself in the same unenviable position as his counterpart in Reit. Braverman, a dentist who discovered that positive comments about his practice had been filtered out after the posting of two negative reviews by anonymous posters, ${ }^{113}$ sued for defamation, alleging that Yelp! had removed all positive reviews of his practice, failed

\footnotetext{
107 Reit v. Yelp!, supra note 96 at 717.

108 Id.

109 Id. at 717.

110 Id. at 718

111 Id.

112 Braverman, supra note 4. Braverman brought another set of actions on slightly different grounds (defamation and breach of contract) in Braverman v. Yelp, Inc. and lost the case, No. 1582992013/2013; aff'd, 128 A.D.3d 568 (2015).

${ }^{113} I d$.
} 
to investigate any reviews and had never contacted him for comments on the negative reviews. ${ }^{114}$ In its defense, Yelp! relied on the CDA in claiming that it could not be held liable as the publisher or speaker of the defamatory statement, but Braverman argued that, in filtering out reviews, including a list of other dentists in a "Best of Yelp list" and charging for advertisements, Yelp! was effectively a content provider. ${ }^{115}$ However, the Court disagreed. As in the Reit decision, it ruled that filtering out positive reviews written by other content providers (i.e., Yelp! users) was not the same as creating or developing content. ${ }^{116}$ Furthermore, the Best of Yelp! list was in a separate section from the user reviews, and thus Yelp! still enjoyed immunity as long as it was not a content provider for the "portion of the statement" at issue. ${ }^{117}$ Likewise, the argument that the Best of Yelp! list was in fact a list of paid advertisers was also insufficient to deprive Yelp! of CDA immunity. ${ }^{118}$

In recognition of the almost insurmountable odds of suing Internet service providers under defamation law, the plaintiff in Davis v. Avvo Inc. decided to tread an alternative legal path, bring action against the defendant for false advertising, the unauthorized use of a likeness for commercial purposes and violations of the Florida 
Deceptive and Unfair Trade Practices Act. ${ }^{119}$ The plaintiff, Davis, was a Florida attorney specializing in health law, whereas the defendant was a Seattle-based website operator providing the profiles of many lawyers, doctors and dentists in the U.S. ${ }^{120}$ and listing areas of practice or specialty, disciplinary history, experience, peer endorsements, and client or patient reviews. ${ }^{121}$ The lawyer section of the website is searchable by area of practice and location. ${ }^{122}$ The information Avvo gathers and posts is publicly available material from state bar associations, state courts, and the websites of lawyers and firms. ${ }^{123}$ Although a listed attorney is unable to change his rating by request, he or she can register on the Avvo website to "claim" his or her profile and update the information on his or her work experience, practice areas and professional achievements, which may in turn have an impact on his or her rating. ${ }^{124}$

Davis discovered that not only was he incorrectly listed on the site as an employment lawyer, but also that he was the "lowest rated employment lawyer" based on a review by a prospective client who had phoned him asking for a discounted legal rate. ${ }^{125}$ Adding to his humiliation, Davis found that he was unable to correct his

\footnotetext{
119 Davis, supra note 3. The plaintiff first filed his action for libel (Id. at 1). Later, he amended the cause of action to claim invasions of privacy/false light (Id. at 2). Finally, he alleged false advertising in violation of Florida Statue section 817.41, the unauthorized use of a likeness for a commercial purpose in violation of Florida Statute 540.08, and violation of the Florida Deceptive and Unfair Trade Practices Act Florida Statue section 501.204 (Id. at 4).

${ }^{120} \mathrm{Id}$. at 1.

121 Id.

${ }^{122} I d$.

$123 \mathrm{Id}$.

${ }^{124} \mathrm{Id}$.

${ }^{125} \mathrm{Id}$. at 2.
} 
practice area or business address on the Avvo website even after registering. ${ }^{126}$

As the defendant was a Seattle-based corporation, and pursuant to a forum selection clause on the Avvo.com website, the case was heard by the Washington State Court, which meant that the defendant was also able to rely on Washington's anti-SLAPP Act (SLAPP stands for Strategic Lawsuits Against Public Participation) to strike out the plaintiff's action. ${ }^{127}$ The anti-SLAPP Act is intended to address lawsuits whose primary purpose is to quash the valid exercise of the constitutional right to free speech under the First Amendment and petition for redress. ${ }^{128}$ According to the Act, a "party may bring a special motion to strike any claim that is based on an action involving public participation." ${ }^{129}$ Once a defendant has proved the existence of public participation, which is defined as including "any oral statement made ... in a place open to the public or a public forum in connection with an issue of public concern" and "other lawful conduct in furtherance of the exercise of the constitutional right of free speech in connection with an issue of public concern...,"130 the burden of proof shifts to the plaintiff, who must demonstrate that there is a substantial case to answer. ${ }^{131}$ If the plaintiff fails to meet that standard, the action is struck out.

In the Court's opinion in Davis, it was obvious that Avvo.com was a website

\footnotetext{
126 Id. at 1.

${ }^{127}$ Id. RCW 4.24.525.

${ }^{128}$ Davis v. Avvo, supra note 3, at 3.

${ }^{129} \mathrm{RCW}$ 4.24.525(4)(a).

${ }^{130} \mathrm{RCW} 4.24 .525(4)(\mathrm{d}) \&(\mathrm{e})$.

131 Davis v. Avvo, supra note 3, at 3.
} 
that involved public participation because it provided information to the general public that might be helpful in choosing a doctor, dentist or lawyer. ${ }^{132}$ In addition, it allowed members of the public to participate in a public forum by providing reviews of individual doctors, dentists or lawyers. ${ }^{133}$ The Court thus concluded that the site was a "vehicle for discussion of public issues ... distributed to a large and interested community."134 Consequently, the burden of proof shifted to the plaintiff, who had to provide clear and convincing evidence that his claim would prevail under Florida law. In analyzing the substantive claims of the plaintiff, the Court found that because the Washington Consumer Protection Act (WCPA) is substantially similar to the Florida Deceptive and Unfair Trade Practices Act, it would apply the WCPA under choice-of-law principles. ${ }^{135}$ To prevail under the WCPA, a plaintiff must prove (1) an unfair or deceptive act or practice, (2) occurring in trade or commerce, (3) affecting the public interest, (4) injury to the plaintiff's business or property, and (5) causation. ${ }^{136}$ In applying the Act, the Court did not consider the rating site to be in trade or commerce, as it does not involve "the sale of assets or services" but "collects data from public sources ... and provides the underlying data and the ratings to consumers free of charge." ${ }^{, 137}$ The publication of information and ratings based on

\footnotetext{
132 Id.

$133 I d$.

134 Id.

135 Id. at 4-5.

136 Id. at 5.

137 Id. at 6.
} 
publicly available data was not "trade or commerce,"138 it ruled, meaning that the alleged misrepresentation of the plaintiff's area of practice or use of his page did not qualify as such. ${ }^{139}$ Furthermore, the plaintiff had not alleged, let alone proved, that he had suffered any actual damage or monetary loss, ${ }^{140}$ and the Court therefore struck out his motion.

It is clear that the U.S. courts are not easily moved by the plight of those faced with misinformation or incorrect information concerning their professional performance posted on rating sites. ${ }^{141}$ Issues of reputation and image simply wither in front of the weighty constitutional amendment on free speech and section 230 of the CDA. ${ }^{142}$

B. German Law

The special nature of evaluation platforms and the possible duties of providers became apparent in the spickmich.de case decided by the German Federal Court in

\footnotetext{
138 Id.

139 Id.

140 Id. at 7.

141 At the time of writing, Hassell v. Bird is pending before the California Supreme Court (247
}

Cal.App.4th 1336; petition for review granted 381 P.3d 231.). The case concerns a law firm that is suing a former client for defamation for posting a false negative review on the Yelp! platform. The California Superior Court entered a default judgment for the plaintiff and ruled that the statement was defamatory, which was affirmed by the Court of Appeals. As that judgment is not disputed, Yelp! was ordered to remove the negative statement. The critical issue before the California Supreme Court is whether an online intermediary should have a right to notice and be given an opportunity to be heard before a trial court orders the removal of online content. Yelp! argues that the case was against s.230 of the CDA and free speech protection under the First Amendment.

${ }^{142}$ Eric Goldman, THE InTERnet RALliES Against A TERRIBLE SECTION 230 Ruling-Hassell V. BIRD TECHNOLOGY \& MARKETING LAW BLOG (2016), http://blog.ericgoldman.org/archives/2016/08/hassell-v-bird.htm (last visited Aug. 4, 2017). 
2009 in which it was asked to rule on the legality of a rating platform. ${ }^{143}$ The plaintiff was a teacher who brought a legal challenge against the popular rating platform spickmich.de. Since its launch in 2007, more than 1.1 million users had registered with the platform, and at the time of the judgment 448,000 teachers had been rated, with their names and teaching subjects given. ${ }^{144}$ Teachers were rated in accordance with various attributes, including whether they were "cool and funny," "humorous" or "popular."145 Student users could also post quotations from their teachers. $^{146}$

The plaintiff was a teacher who had received 4.3 out of a total mark of 6 , which was equivalent to a bare pass in the German system. ${ }^{147}$ She sought a prohibitory injunction in a lower court to stop the publication of her personal information (i.e., her name, the name of her school, her scores on the website and any comments made in class) under the Civil Code, ${ }^{148}$ filed for the deletion of her personal data and argued that the platform had infringed her privacy right under the

\footnotetext{
${ }^{143}$ Spickmich.de, BGH 23.06.2009, VI ZR 196/08, published in NJW 2009, 2888 et seq. The applicant applied for leave to appeal before the Constitutional Court but the complaint was declared to be inadmissible, decision of 16 October 2010, Bundesverfassungsgericht Case 1 BvR 1750/09. The facts of the case are based largely on the case discussion in Florian Wagner-Von Papp and Jorg Fedtke, Germany, in EUROPEAN TORT LAW: BASIC TEXTS (Barbara C. Steininger Ken Oliphant ed. 2011). and Andreas Ruehmkorf, Displease Sir: Teacher Rating Legality, Society for Computers \& Law, available at http://www.scl.org/site.aspx?i=ed13764.

${ }^{144}$ Ruehmkorf, $i d$.

${ }^{145}$ BGH, NJW 2009, 2888.

146 Id.

147 Id.

148 Sections 823 and 1004 of the BGB govern tortious liability and an application for injunction, respectively. For the relevant provisions in English, see GERMAN CIVIL CODE, http://www.gesetze-im-internet.de/englisch_bgb/englisch_bgb.html\#p3484.
} 
Federal Data Protection Act (Bundesdatenschutzgesetz, BDSG). ${ }^{149}$ In addition, she claimed that the category of "quotations" infringed her right to her own spoken words. ${ }^{150}$ Another of the teacher's arguments was that teachers and users were not on equal terms on the site, as, unlike the former, the latter were able to remain anonymous because they did not have to provide usernames. ${ }^{151}$

The spichmich.de case was unique in blurring the boundaries of the different objects of protection in the right of personality under the Basic Law. In deciding it, the Court did not rely primarily on the general right of personality, but rather on the right to informational self-determination, which, on the sub-constitutional level, is protected by the Federal Data Protection Act. However, in its balancing it used arguments that stem from cases concerning the general right to privacy.

Under section 29(1) of the Federal Data Protection Act, the commercial collection, storage, modification or use of personal data for the purpose of transfer is permissible without the consent of the person affected if "there is no reason to believe that the data subject has a legitimate interest in excluding such collection, storage or modification.”"152 The Court interpreted that provision as a test for weighing up the

\footnotetext{
149 Bundesministerium der Justiz und für Verbraucherschutz (Federal Ministry of Justice and Consumer Protection ) FEDERAL DATA PROTECTION ACT,

http://www.gesetze-im-internet.de/englisch_bdsg/index.html.

${ }_{150}$ BGH, NJW 2009, 2888 (2894 recital 5, 46).

151 BGH, NJW 2009, 2888 (2889 recital 5).

152 BGB, supra note 49.
} 
conflicting legitimate interests of the plaintiff and defendant. ${ }^{153}$ On the plaintiff's side, her claim of privacy rested on section 823(1) of Civil Code in conjunction with articles 2(1) and 1(1) of the Basic Law, which protect personality and dignity rights, respectively. ${ }^{154}$ On the defendant's side, the right to freedom of expression, which is protected under article 5(1) of the Basic Law, was invoked. As discussed earlier, it is well established under German law that the right of personality encompasses various dimensions. $^{155}$

For the case at bar, it was the right to informational self-determination that came into play. That right protects an individual's choice to decide when and within which limits his or her personal life circumstances are revealed, particularly in the age of data processing. ${ }^{156}$ Furthermore, the right's scope is dependent on the spheres affected: the intimate, private or social. ${ }^{157}$ Corresponding to the discussion in Part II.B of this article, ${ }^{158}$ the first sphere warrants the highest degree of protection, as it concerns the inviolable core of the personal sphere (e.g., sexual orientation). The

\footnotetext{
${ }^{153}$ Michael Schmidt, Privacy Laws in Germany - Development over Three Decades, IITR GmbH Institut für IT-Recht (2012), available at http://www.iitr.us/publications/41-privacy-laws-in-germany-developments-over-three-decades.html. ${ }^{154}$ BASIC LAW FOR THE FEDERAL REPUBLIC OF GERMANY, http://www.gesetze-im-internet.de/englisch_gg/englisch_gg.html\#p0019.

${ }^{155}$ The right of personality protects one's honor, private sphere, data protection and informational self-determination.. See supra Part I.B.

${ }^{156}$ Schmidt, supra note 153.

157 Andreas Ruehmkorf, Ratemylegalrisk.com - The Legality of Online Rating Sites Relating to Individuals in Data Protection Law, 96 InTELLECTUAL PROPERTY FORUM 55-67 (2014), available at http://eprints.whiterose.ac.uk/88313/.

${ }^{158}$ Handford, supra note 50.
} 
second allows intrusions only if they are justifiable and proportionate, and the third merits the least protection because it concerns an individual's social life. ${ }^{159}$

In the Court's opinion, the online platform had touched only upon the social sphere of the plaintiff because the rating concerned her professional performance and conduct as a teacher. ${ }^{160}$ It thus held that freedom of expression overrode her right to informational self-determination because teachers and other professionals must accept criticism or applause of their professional conduct, which is inevitably intertwined with social life. ${ }^{161}$ As the rating site related only to the plaintiff's professional/social sphere, that is, did not touch upon her core private sphere, the right of personality had to give way to freedom of expression. In addition, the Court also highlighted that freedom of expression protects anonymous opinions because antipode would lead to self-censorship. It further pointed out that if the posts had been abusive or offensive or amounted to an attack on the teacher's dignity, then its decision would have been different. ${ }^{162}$ Each case has to be decided on its own facts. However, it is worthwhile noting the features of spickmich.de that led the Court to conclude that the case constituted a reasonable exercise of freedom of expression: the site permitted only one registration per e-mail address; distribution was restricted to current students; log-in

\footnotetext{
159 Id.

160 BGH, NJW 2009, 2888 (2892 recital 31).

161 BGH, NJW 2009, 2888 (2892 recital 32 et seq.).

162 BGH, NJW 2009, 2888 (2892 recital 34); Andreas Ruehmkorf, Displease Sir: Teacher Rating Legality Society for Computers and Law, THE IT LAW COMMUNITY (2009), available at https://www.scl.org/articles/1663-displease-sir-teacher-rating-legality.
} 
and registration were required; users had to select a particular school and could rate and view ratings on teachers within that school alone; data were retained for no longer than one year; no comments were allowed; and ratings were not visible on search engines. ${ }^{163}$

Subsequent litigation concerning rating sites has largely followed the principles set in the spickmich.de case: namely, a plaintiff is not entitled to know the identity of a poster after a website has removed derogatory comments, ${ }^{164}$ and doctors should expect to face "open criticism" in the form of online ratings. ${ }^{165}$ With regard to the issue of misleading ratings, which did not arise in the spickmich.de case, the German courts have been rather more skeptical and unsympathetic toward rating platforms. For instance, when the U.S. company Yelp! bought the German rating platform Qype in 2012, it changed its modes of both operation and rating. ${ }^{166}$ Similar to the practice noted in our earlier discussion of the U.S. lawsuits against Yelp!, after its purchase Qype started filtering out positive comments on many businesses while retaining negative comments, which resulted in the massive downgrading of many business entities. For example, in one case, the plaintiff ran a bridal dress shop that had previously received a five-out-of-five-star rating but suddenly found itself with a

163 BGH, NJW 2009, $2888(2888,2889$ recital 4).

164 BGH, 1.7.2014, VI ZR 345/13 - OLG Stuttgart - LG Stuttgart (Sanego).

165 BGH 23.9.2014 - VI ZR 358/13 - LG Muenchen/AG Muenchen (Jameda).

166 Ingrid Lunden, Yelp Pays \$50M To Acquire Its Big European Rival, Qype, To Beef Up Its Recommendations And Listings Business, TECHCRUNCH, 2012, http://social.techcrunch.com/2012/10/24/yelp-pays-50m-to-acquire-its-big-european-rival-qype/ (last visited Aug. 4, 2017). 
mere two-star rating under the new system, leading to a significant drop in business. ${ }^{167}$ Accordingly, the shop brought an action for violation of its right of personality. ${ }^{168}$ The court ruled in the plaintiff's favor, and held that although companies do not enjoy a right of personality as extensive as that enjoyed by a person, it was by no means clear that deleting the posts constituted an exercise of freedom of expression. ${ }^{169}$ Similarly, in another case the court condemned the rating portal Jameda when it heard that its top-rated doctors list was "manipulated by purchase."170 It ordered that Jameda must either cease the practice of posting such misleading comments about doctors or state clearly that the list was an advertisement. ${ }^{171}$ This jurisprudence of the BGH shows the two main issues of online rating: the lack of transparency regarding the rating criteria and the conflict between free speech and right to self-determination.

\section{Searching for Alternatives}

In juxtaposing the U.S. and German legal approaches to the regulation and protection of reputation on online rating platforms, we have learnt about the potential and power of reputational sanctions. U.S. judicial decisions, as demonstrated by the

\footnotetext{
${ }^{167}$ LG Berlin, 27.3.2014 - 27 O 748/13 (Yelp).

$168 I d$.

169 Id.

170 Ekkehard Müller-Jentsch, Portal muss irreführende Beurteilungen über Ärzte stoppen, SUEDDEUTSCHE.DE, March 19, 2015, http://www.sueddeutsche.de/muenchen/landgerichts-urteil-irrefuehrende-beurteilungen-1.2401184. ${ }^{171} I d$.
} 
cases discussed herein, exhibit lopsided favoritism toward online free speech despite some rating sites posting blatantly inaccurate information and only one-sided negative reviews, leaving victims with few remedies other than paying online reputation companies to rebuild their reputations. The U.S. approach thus supports an unsatisfactory situation in which individuals have very little control over their reputations, which are thus left in the hands of others. The German courts, in contrast, have adopted a more nuanced approach in which the evaluation of and opinions on an individual are treated as belonging to the constitutionally protected right of personality. The German Constitutional Court has recognized that personal comments can in certain situations intrude into the personal sphere, and have also engaged in careful scrutiny of the various zones of the that sphere, with the most intimate private sphere prized as inviolable. In the cases considered above, the courts carefully balanced the personal and social spheres and the right of personality (right to informational self-determination) and right to freedom of expression. What the German courts have thus far failed to do is to address the overlap between the private and social spheres. Evaluations of professional performance often touch upon personal characteristics and abilities such as a sense of humor. In the spickmich.de case, it was revealed that the rating portal had previously included a category allowing student users to consider whether a teacher was sexy, but that category was removed 
during the course of litigation. ${ }^{172}$ In post-spickmich judicial decisions, the German courts have endeavored to devise a fair system of online reputation rating, with distinctions drawn between different rating subjects (businesses or persons), different rating criteria and different access systems. In a recent case a German district court also acknowledged a violation of the social sphere when information about bankruptcy was revealed without consent and against the will of the concerned individual. ${ }^{173}$ It therefore does not need to be a violation of the most private sphere to affect somebody's right to self-determination.

Neither the U.S. nor German legal systems really takes into account the actual practices and informal norms of online platform users. However, by focusing on the platforms themselves and their liability, the law in both has indirectly influenced the way in which providers design the context of user interactions. Hence, providers have become intermediaries, moderating the relationship between informal social norms and formal law, although it remains unclear what that means for conflict resolution and behavior coordination on rating platforms.

The cases discussed herein suggest that the major causes of frustration for plaintiffs are the lack of transparency concerning evaluation criteria and the unavailability of any means of response (including a right to reply, request a

\footnotetext{
${ }^{172}$ RUEHMKORF, supra note 132. RATEMYLEGALRISK.COM, supra note 130.

173 AG Rockenhausen, Urt. v. 9.8.2016 - 2 C 341/16
} 
correction and demand a retraction). Hence, effective disclosure requirements and an opportunity to present the other side of the story are essential to ensuring the fairness and accuracy of online reputation systems. Frank Pasquale advocates the mandatory disclosure of ranking data and methodologies to tackle the problem of "black-box" evaluation systems. ${ }^{174}$

In addition, it is also important that online evaluation sites that affect people's professional reputation comply with the additional requirement to delete inaccurate information and bar decontextualized ratings. As previously noted, reputation as property has a special market value attached that can affect a person's livelihood. It is thus necessary for such sites to provide a correction mechanism or a right to reply. In clear cases of erroneous information (as in the case of Davis v. Avvo ${ }^{175}$ ), a mechanism should be in place to allow corrections when objective information can be easily established.

A trickier issue is how to decide when, whether and how to include an alternative story. In Part II, we discuss cases in which evaluation sites had filtered out positive consumer comments while retaining negative ones, an understandably frustrating and seemingly unfair situation for the targeted individuals. Concerned platforms should thus allow individuals to exercise a right of response to defend

${ }^{174}$ Frank Pasquale, Reputation Regulation: Disclosure and the Challenge of Clandestinely Commensurating Computing, in THE OFFENSIVE INTERNET: SPEECH, PRIVACY, AND REPUTATION 107, 120 (Saul Levmore \& Martha C Nussbaum eds., 2010).

175 Davis v. Avvo, supra note 3. 
themselves. For example, in the online platform ratemyprofessors.com, students can

rate their professors and post comments. At the same time, however, professors can also "strike back" and offer their own views of their teaching. ${ }^{176}$

What we are emphasizing is the need to arrive at a standard that is fair to platform providers, users and evaluation targets. At the state level, U.S. insurance companies have agreed to follow specific guidelines on ranking doctors based on a national model established by the federal government. ${ }^{177}$ At the private level, attempts to set guidelines may involve a complex interaction of social norms, as seen in disputes concerning Wikipedia-related reputation issues. ${ }^{178}$ Although Wikipedia is not an evaluation site, the user-generated online encyclopedia provides a standard procedure for complainants looking to protect their reputation, ${ }^{179}$ and applies a more stringent standard for biographies of living persons. ${ }^{180}$ Information on a living person

\footnotetext{
176 Rate My Professors - ReVIeW Teachers and Professors, SchoOl ReVIEWS, COLlege CAMPus RATINGS, http://www.ratemyprofessors.com/blog/profstrikesback?posturl=/the-best-of-professors-strike-back/. ${ }_{177}$ At the national level, a rating list of doctors must pass federal regulations before it can be used. Amy Goldstein, Federal Health Officials, Insurers Agree on How to Rate Doctors' Quality, THE WASHINGTON POST, February 16, 2016,

https://www.washingtonpost.com/national/health-science/federal-health-officials-insurers-agree-on-ho w-to-rate-doctors-quality/2016/02/16/e87934b0-d4d4-11e5-9823-02b905009f99_story.html?utm_term $=.2 \mathrm{da} 3 \mathrm{dc} 00 \mathrm{c} 312$. At the state level, the California Healthcare Performance Information system, which scores 10,000 doctors, was launched in March 2017. Paul Sisson, How Does Your Doctor Rank? Check Out this New Website, THE SAN DIEGo UnION TRIBUNE, March 28, 2017, http://www.sandiegouniontribune.com/news/health/sd-me-doctor-ratings-20170327-story.html.

${ }_{178}$ Ken S Myers, Wikimmunity: Fitting the Communications Decency Act to Wikipedia, 1 HARV. J. LAW TECHNOL. 163 (2006).

${ }_{179}$ Wikipedia: Help: Contents https://en.wikipedia.org/wiki/Help:Contents (last visited Aug. 1, 2017).

${ }^{180}$ Wikipedia: Biographies of living persons https://en.wikipedia.org/wiki/Wikipedia:Biographies_of_living_persons (last visited Aug. 1, 2017).
} 
that is unsourced, poorly sourced or contentious must be removed immediately. ${ }^{181}$ In addition, every article on Wikipedia has a "talk" page that allows users to post comments on or concerns about the article. ${ }^{182}$ Furthermore, administrators can also block an article, require that additional revisions be flagged or ban a user, ${ }^{183}$ although offended users are accorded a right of appeal. ${ }^{184}$ In sum, Wikipedia's posting policy and dispute-handling mechanism adhere to the principles of transparency and the rights of response and appeal, and address the needs and concerns of both users and subjects.

Ultimately, what we need are different sets of etiquette for different rating systems because the public interest at risk in the external social and internal private spheres is markedly different. The implementation of such sets would not only benefit the individuals scored or evaluated, but also the users of reputation and evaluation platforms and, ultimately, society as a whole. Recalling our earlier discussion of Post, reputation is by nature social, public and relational. ${ }^{185}$ Evaluation sites thus need to fulfill the social role of assigning fair value to reputation and sending an accurate signal to the community if they want to be reliable and meaningful to consumers.

\footnotetext{
181 Id.

182 Wikipedia talk: About https://en.wikipedia.org/wiki/Wikipedia talk:About (last visited Aug. 1, 2017).

183 Wikipedia: Blocking policy https://en.wikipedia.org/wiki/Wikipedia:Blocking_policy (last visited Aug. 1, 2017).

184 Wikipedia: Appealing a block https://en.wikipedia.org/wiki/Wikipedia:Appealing_a_block (last visited Aug. 1, 2017).

185 See supra Part I.A.
} 


\section{Conclusion}

Reputation is a mysterious ${ }^{186}$ and powerful thing. It is intensely personal and innately social at the same time. It concerns one's own identity, yet is also intertwined with social appraisal in the minds of others. Regardless of how carefully we groom and shape our reputations, the final judgment rests in the hands of others. Like it or not, in today's networked community, we have become objects vulnerable to having various aspects of our lives ranked, scored, evaluated and commented upon by anonymous others. U.S. defamation law seems inadequate to protect individuals against the ratings and comments of an unknown crowd. German law on the right to personality has developed a taxonomy of spheres to protect the personal and situate it in relation to the social. Although U.S. and German laws protect different aspects of reputation, they have generally achieved the same effect in restricting the flow of information on individuals and preventing harm to their social status and private lives. However, the reputation sphere is expanding rapidly in the online world, ${ }^{187}$ bringing new challenges to individuals, users, platform operators and society as a whole.

Although different legal rights have been identified and fought for, the reputation interest remains the same. What has yet to be addressed is the issue of how to develop a new procedural layout that can accommodate social norms, technological

\footnotetext{
186 Post, supra note 34.

187 David Ardia, Reputation in a Networked World: Revisiting the Social Foundations of Defamation Law, HARV CR-CL REV 261, 303 (2010).
} 
advancement and the legal right to protect reputation on online platform. In this article, we have identified the personal rights and interests involved in reputation, the societal interests in freedom of expression and the necessity of establishing a reliable system for assessing reputation, particularly in the professional context. Rather than leave individuals to seek help from private corporations in attempting to rescue and manage their reputations, our legal systems should require evaluation platforms to comply with a set of minimum procedural standards of fairness. What is particularly required for online ranking and rating sites is a set of transparency rules that inform users of the assessment criteria, as well as a system offering aggrieved individuals a right to reply. The latter should incorporate rights to respond, to openly rebut allegations, to correct information and to request the retraction of information. As evaluation platforms are gaining in popularity and shaping public communication, we need a new set of policies and practices to regulate the online ecology and protect reputation. Only then can we interact and participate meaningfully in constructing our own and others' reputations. 